\title{
Revision of the genus Coccidula Kugelann (Coleoptera, Coccinellidae)
}

\author{
Karol Szawaryn', Oldřich Nedvěd ${ }^{2,3}$, Amir Biranvand $^{4}$, \\ Tomasz Czerwiński', Romain Nattier ${ }^{5}$
}

I Museum and Institute of Zoology, Polish Academy of Sciences, Wilcza 64, 00-679 Warszawa, Poland 2 Faculty of Science, University of South Bohemia, Branišovská 1760, CZ-37005 České Budèjovice, Czech Republic 3 Czech Academy of Sciences, Biology Centre, Institute of Entomology, České Budéjovice, Czech Republic 4 Department of Entomology, College of Agricultural Sciences, Shiraz Branch, Islamic Azad University, Shiraz, Iran 5 Institut de Systématique, Evolution et Biodiversité (ISYEB), Muséum national d'Histoire naturelle, CNRS, Sorbonne Université, EPHE, Université des Antilles, 57 rue Cuvier, CP 50, 75231, Paris Cedex 05, France

Corresponding author: Karol Szawaryn (k.szawaryn@gmail.com)

Academic editor: J. Poorani | Received 11 March 2021 | Accepted 5 May 2021 | Published 11 June 2021

http://zoobank.org/B6FC6D94-EC85-4EFC-8CEF-6F2D7E67059D

Citation: Szawaryn K, Nedvěd O, Biranvand A, Czerwiński T, Nattier R (2021) Revision of the genus Coccidula Kugelann (Coleoptera, Coccinellidae). ZooKeys 1043: 61-85. https://doi.org/10.3897/zookeys.1043.65829

\begin{abstract}
The genus Coccidula Kugelann includes five species distributed in the Holarctic, with one species in North America and four in Palearctic region. Coccidula belongs to the tribe Coccidulini which historically was treated as a separate subfamily within ladybird beetles, but recent studies confirmed its placement as a tribe within the broadly defined subfamily Coccinellinae. All species are revised and a new synonymy of Lithophilus naviauxi Duverger with C. litophiloides Reitter is proposed. Light and electron microscopy pictures support morphological descriptions. An identification key to all species is also provided.
\end{abstract}

\section{Keywords}

Coccinelloidea, ladybirds, morphological revision, new synonym, taxonomy

Copyright Karol Szawaryn et al. This is an open access article distributed under the terms of the Creative Commons Attribution License (CC BY 4.0), which permits unrestricted use, distribution, and reproduction in any medium, provided the original author and source are credited. 


\section{Introduction}

The classification of ladybird beetles (Coccinellidae) has changed dynamically in the last decade mainly due to molecular approaches. Although several studies have been conducted at the family level, none of them gave robust classification of the family (Seago et al. 2011; Robertson et al. 2015). Historically, the family was divided into six or seven subfamilies (Sasaji 1968; Kovár 1996) but more recent treatments based on morphology and molecules support just two, Microweiseinae and Coccinellinae (Ślipiński 2007; Seago et al. 2011; Robertson et al. 2015). However, recent analysis of a large molecular dataset (Che et al. 2021) revealed the existence of the third monotypic subfamily Monocoryninae.

The genus Coccidula Kugelann, 1798 was traditionally placed in the subfamily Coccidulinae (Sasaji 1968; Kovár 1996), nonetheless, in the new classification of ladybirds it was proposed to be one of the tribes (Coccidulini) within the broadly defined subfamily Coccinellinae. Seago et al. (2011) synonymized this tribe with Scymnini, however, after the analyses by Robertson et al. (2015) and Che et al. (2021) both are once again treated as independent tribes. Coccidulini are one of the most problematic groups of ladybirds as in the traditional classification they contain numerous genera with just superficial external similarity based mainly on hairy body surface and relatively long antennae. Consequently, in all molecular analyses they do not form a monophyletic group (Seago et al. 2011; Robertson et al. 2015; Che et al. 2021). The tribe is distributed worldwide with moderate diversity in the Palearctic (Kovár 2007) and African regions (Fürsch 2007; Tomaszewska 2010), rich in South America (Gordon 1994), but the most diverse fauna occurs in South Asia, Australia and neighboring regions (e.g., Ślipiński 2007; Poorani and Ślipiński 2009; Tomaszewska 2010; Tomaszewska and Ślipiński 2011; Szawaryn and Leschen 2019). The largest and most widely distributed is the genus Rhyzobius Stephens, 1831 with more than 100 recognized species (Tomaszewska 2010; Czerwiński et al. 2020) and numerous undescribed species mainly from New Guinea. Interestingly it is also the only genus of Coccidulini with known fossil representatives from the Eocene period discovered in Oise (Kirejtshuk and Nel 2012) and Baltic ambers (Szawaryn and Tomaszewska 2020).

Coccidula is a small genus distributed in the Holarctic, with one species in North America and four in Eurasia. Historically numerous species and varieties have been described based mostly on differences in color pattern, but most of them were subsequently synonymized when genitalia were examined. Gordon (1985) revised the North American species; however, the Palearctic species have not been revised until now. As Coccidulini has never been a subject of morphological cladistic analysis there is no hypothesis about its internal relationship available. However, based on recent molecular analyses (Che et al. 2021), C. scutellata (Herbst, 1783) and Rhyzobius litura (Fabricius, 1787) group in a single clade with the African genus Epipleuria Fürsch, 2001 and African species of Rhyzobius.

The European species are usually found in wetlands and water banks in low and middle elevations (Bielawski 1959). They live on herbaceous emergent grassy 
vegetation such as reeds, feeding on aphids such as Hyalopterus pruni (Hemiptera: Aphididae). Coccidula rufa is sometimes contrastingly reported also from dry sand dunes and in Finland from cereal fields (Clayhills and Markkula 1974). High prevalence (60-80\%) of endosymbiotic bacteria Rickettsia and Wolbachia was reported from Germany (Weinert et al. 2007). Coccidula rufa is univoltine - mating and egg-laying occur in the spring and summer, eggs are laid in batches on reed stems and foliage, larvae develop through the spring and summer, and a new generation of adults emerges in July. All species may be locally and temporally abundant.

The tribe Coccidulini needs comprehensive revision. In the current work we present a morphological revision of all currently known species of Coccidula, the type genus for the tribe. This revision is a first step to understand the morphological diversity of the tribe and may lead to further phylogenetic studies.

\section{Material and methods}

Material used of this study is deposited in the following collections:

$\begin{array}{ll}\text { AJC } & \text { Andrzej Jadwiszczak Collection, Poland; } \\ \text { ASC } & \text { Alexander Slutsky Collection, Kharkov, Ukraine; } \\ \text { HNHM } & \text { Hungarian Natural History Museum, Budapest, Hungary; } \\ \text { NMP } & \text { National Museum Prague, Czech Republic; } \\ \text { MIZ } & \text { Museum and Institute of Zoology, Warsaw, Poland; } \\ \text { MNHN } & \text { Muséum national d'histoire naturelle, Paris, France; } \\ \text { USB } & \text { University of South Bohemia, České Budějovice, Czech Republic. }\end{array}$

Genitalia were dissected, cleared in a $10 \% \mathrm{KOH}$ solution, washed in water, and placed in glycerol on slides for further study. Female genitalia were stained with chlorazol black. Measurements were recorded as follows: TL - total body length from apical margin of clypeus to apex of elytra; PL - pronotal length from the middle of anterior margin to the middle of the posterior margin; PW - pronotal width across widest part; EL - elytral length along suture including scutellum; EW - elytral width across both elytra at the widest part. Colour images were taken using either a stereo microscope Leica MZ 16 with a digital camera IC 3D; final images were produced using Helicon Focus 5.0X64 and Adobe Photoshop CS6 software, or a stereo microscope Nikon SMZ 1500 with Lumenera digital camera and QuickPhoto software, composite images with deep focus were generated using Zerene Stacker. The SEM photographs were taken in the Laboratory of Scanning Microscopy, MIZ (Warsaw), using a scanning electron microscope HITACHI S-3400N under low vacuum conditions and on JEOL JSM-7401F in Biology Centre CAS (České Budějovice). Terminology used for morphology follows Ślipiński (2007) and Lawrence et al. (2011). In this paper, we follow the classification proposed by Che et al. (2021). 


\section{Taxonomy}

\section{Family Coccinellidae Latreille, 1807 \\ Subfamily Coccinellinae Latreille, 1807 \\ Tribe Coccidulini Mulsant, 1846}

\section{Coccidula Kugelann, 1798}

Coccidula Kugelann, 1798: 421. Type species: Chrysomela scutellata Herbst, 1783, by subsequent designation by Crotch 1874 .

Strongylus Panzer, 1813: 114.

Cacidula Dejean, 1821: 132. Type species: Chrysomela pectoralis Fabricius, 1792 (=Dermestes rufus Herbst, 1783).

Cacicula Stephens, 1831: 397.

Diagnosis. Representatives of the genus Coccidula with its general body shape may resemble Tetrabrachys Kapur, however, it can be separated based on the structure of the tarsi which are tetramerous in both genera but in Coccidula the first tarsomere is sub-triangularly broadened apically and the second is elongate and distinctly lobbed, while in Tetrabrachys both the first and second are narrow, elongate and without lobes. Moreover, in Tetrabrachys the apical maxillary palpomere is widely securiform, and beetles are brachypterous, while in Coccidula the apical maxillary palpomere is only slightly widened and the second pair of wings is functional. Coccidula is also externally similar to European species of Rhyzobius but it can be separated based on the following characters: body almost parallel sided, elytra covered with punctures of two sizes, larger punctures arranged in nine rows (in C. litophiloides some of them are reduced), base of the pronotum not bordered, while in Rhyzobius the lateral body outline is broadly rounded, the elytra are covered with single sized, randomly arranged punctures, and base of the pronotum with distinct bordering line.

Description. Body elongate-oval, with sides parallel (Fig. 1C-H), body flattened in lateral view, convex in cross-section; dorsum covered with setiferous punctures of two sizes (Figs 7A, 9A), hairs directed forwards on pronotum, backwards on elytra.

Head partially withdrawn into prothorax (Fig. 1C-H); ventral antennal grooves shallow and moderately long, extending to posterior border of an eye (Fig. 3E). Eyes prominent, coarsely facetted (7-8 ommatidia per eye width), ocular canthus distinct, about as long as 4-5 ommatidium diameters; interocular distance about $3 \times$ as eye diameter; interfacetal setae present only in basal part; temple behind eye distinctly longer than eye (Fig. 3E). Antennal insertion placed laterally, invisible from above, distance between antennal insertions about same as between eyes; frons around antennal insertions slightly expanded, covering antennal insertions, anterior tentorial pits placed ventrally below antennal insertions. Antennae (Figs 5A, E, 7A, D) longer than maximum head width including eyes, composed of 11 antennomeres (AN); scape simple, without projections, slightly curved; pedicel distinctly narrower than scape, elongate (1.5x longer than wide); AN 3-8 elongate (AN3 $\approx 3.5 \times$; AN8 $\approx 1.3 \times$ longer than wide); AN 

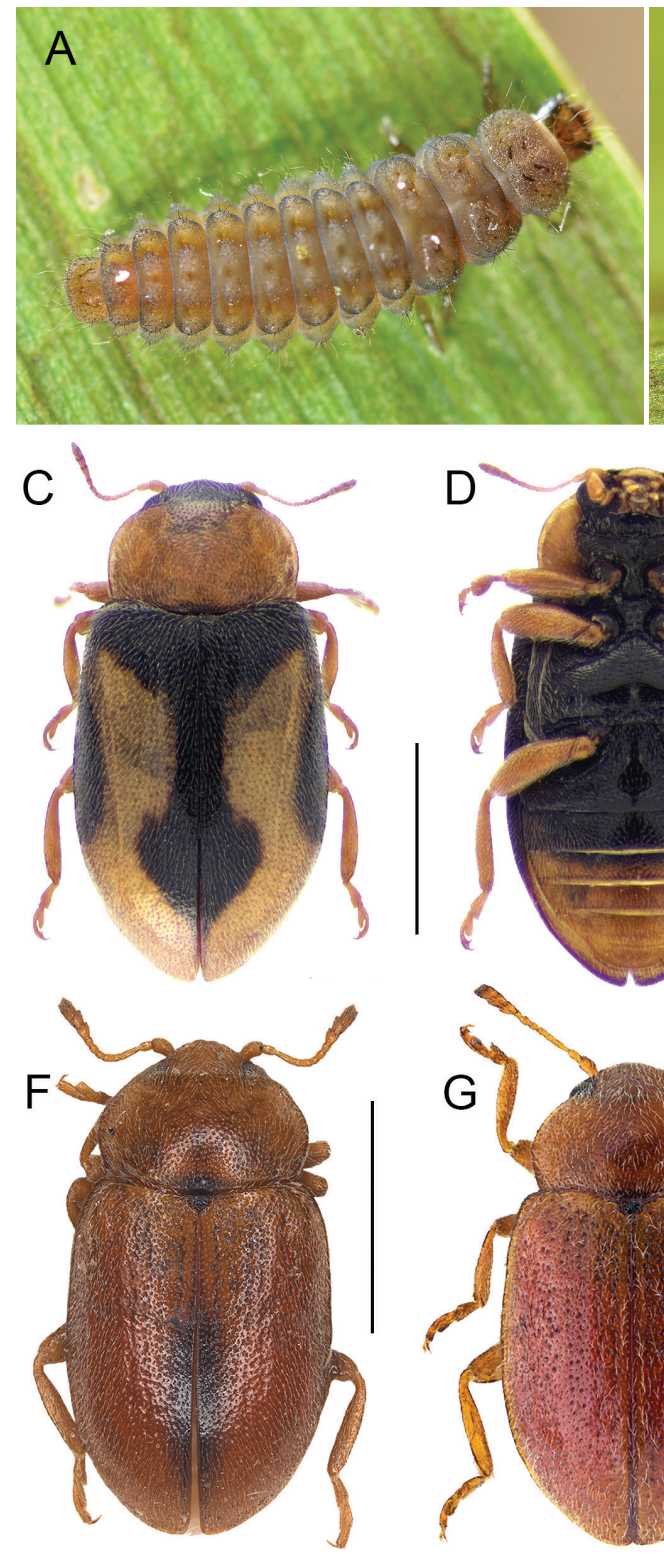
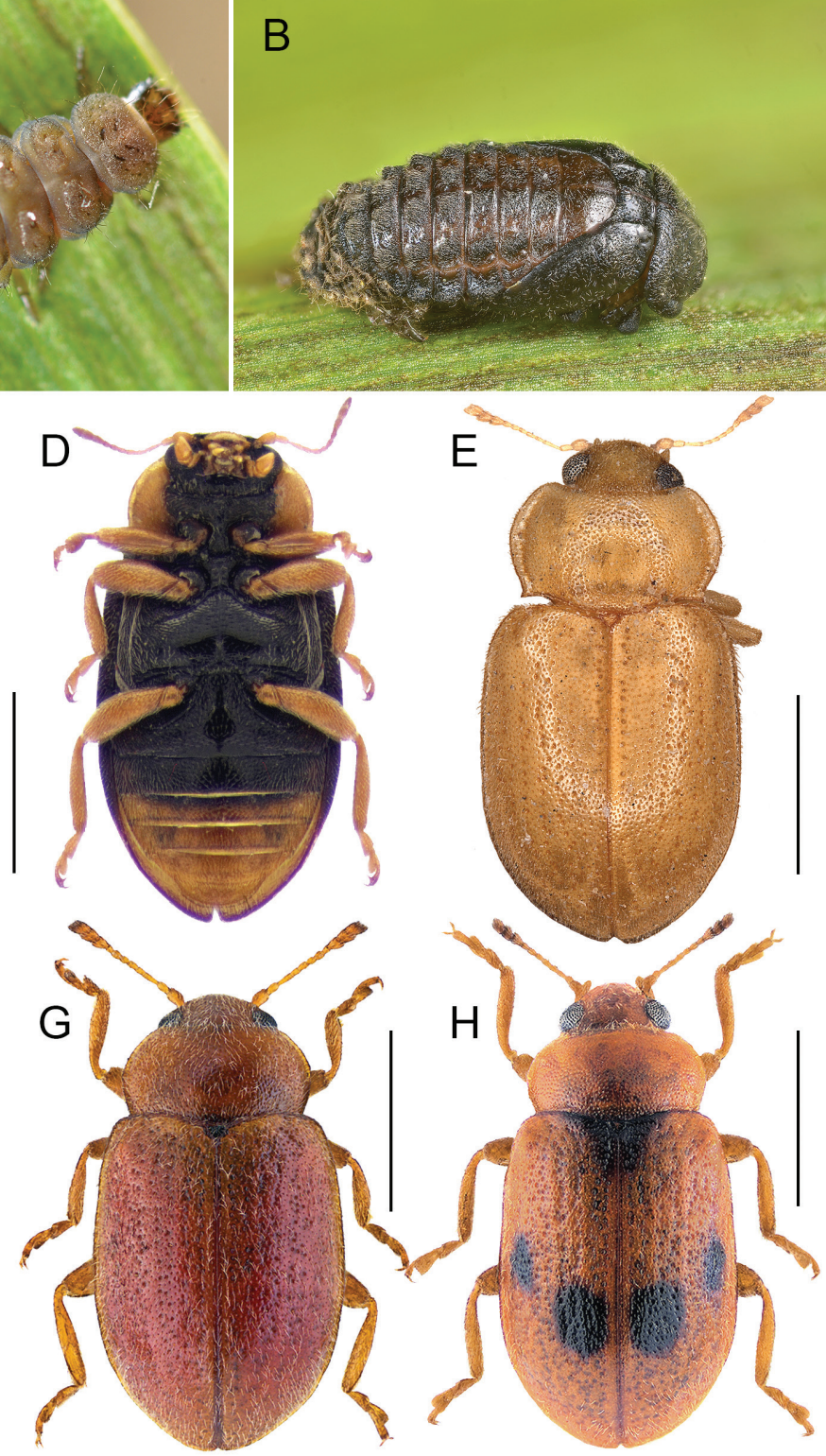

Figure I. Immature stages and habitus of adult species of Coccidula Kugelann A C. rufa larva B C. rufa pupa C C. lepida, dorsal D C. lepida, ventral $\mathbf{E}$ C. litophiloides $\mathbf{F}$ C. reitteri $\mathbf{G}$ C. rufa $\mathbf{H}$ C. scutellata A, B Gilles San Martin, Wikimedia Commons C, D Danny Haelewaters G, H Udo Schmidt. Scale bars: $1 \mathrm{~mm}(\mathbf{C}-\mathbf{H})$.

9-11 forming a loose, asymmetric club, ultimate AN truncate apically. Frontoclypeus short, transverse, anterior margin straight. Labrum entirely exposed, transverse, anterior margin straight. Mandibles asymmetric, bifid apically (Fig. 10G), molar part with basal tooth; prostheca distinct. Maxillary stipes (Figs 2B, 5C, 9C, 10H) with distinct groove for reception of maxillary palp in repose; palpomere 2 shorter than terminal 
$\left(4^{\text {th }}\right)$ one, slightly broadened apically; palpomere 3 about $2.3 \times$ shorter than terminal one, subtriangular; terminal palpomere slightly securiform; lacinia with stiff setae on outer margin in apical half, with several additional spurs on surface (Fig. 10H). Labial palps (Figs 3E, 9C) with 3 palpomeres, inserted ventrally on prementum; palpomere 1 very small, apical palpomere as long as and about as broad as penultimate; distance between palp insertions about 1.5-2x as its width. Prementum subquadrate, transverse apically. Mentum trapezoidal, broadest in anterior part, with horseshoe impression at base (Figs 7C, 9C). Submentum broad, transverse, with suture invisible.

Anterior margin of pronotum weakly, broadly emarginate (Figs 3B, 5B) with anterior corners broadly rounded; lateral margins with moderately (Figs 7B, 9B) to distinctly expanded lateral beads (Fig. 3B), distinctly margined; hind corners sharply pointed; hind margin not bordered. Prothoracic hypomeron smooth, without delimited foveae (Figs 3C, 7C). Prosternum in front of coxae about as long as longitudinal length of procoxal cavity; anterior margin straight or slightly emarginate with distinct border. Prosternal process about 0.4 times of coxal diameter, surface smooth (Fig. 3C) or with lateral carinae (Figs 7C, 9E). Procoxal cavity oval, distinctly bordered anteriorly.

Mesoventrite $1.3 \times$ longer than its width at the level of mid coxae (Figs 1D, 5D, 7D); mesal surface with deep emargination for receiving tip of prosternal process (Fig. 2C); anterior margin with completely raised border. Meso-metaventral process narrow (Figs $1 \mathrm{D}, 2 \mathrm{C}, 5 \mathrm{D}, 7 \mathrm{E}$ ), about 0.5 times of mesocoxal diameter, junction slightly arcuate (Figs 2C, 3D, 5D, 7E, 9D), with suture visible. Metendosternite with stalk sub-quadrate, tendons long, separated by a distance of about width of stalk and situated closer to center (Fig. 10I). Scutellar shield pentagonal (Figs 7B, 9B). Elytra at base wider than pronotum, lateral margins clearly visible from above throughout (Figs 2D, 3A, 5A, 7A) (except $C$. scutellata where it is obscured in basal part, Fig. 9A), surface covered with punctures of double size, smaller irregularly distributed, larger punctures arranged in nine irregular longitudinal rows. Sutural stria absent. Elytral epipleuron narrow, incomplete, reaching base of ventrite 4 (Fig. 1D), with complete bordering line, epipleural foveae absent. Hind wings fully developed or missing (in C. litophiloides). Metaventral postcoxal lines roundly joined medially, complete laterally, straight or descending (Figs $2 \mathrm{C}, 3 \mathrm{D}, 5 \mathrm{D}, 7 \mathrm{E}, 9 \mathrm{D})$. Metaventrite with discrimen visible in posterior $2 / 3$.

Trochanters simple, subtriangular, without projection (figs 7E, 9D). Tibiae slightly expanded apically with one apical spur on forelegs, and two in mid and hind legs. Tarsi consisting of four tarsomeres, second tarsomere truncate apically; tarsal claws cleft apically (Fig. 9G) with single empodial seta present.

Abdomen in both sexes with 6 ventrites (Fig. 1D); ventrite 1 about as long as ventrites 2-4 combined, ventrite 2 longer than ventrite 3, ventrites 3-5 subequal in length. Abdominal postcoxal lines (Figs 7E, 9D) separate medially, recurved and complete, reaching anterior margin of ventrite, posteriorly reaching about half length of ventrite 1 . Ventrite 5 in female posteriorly rounded (Fig. 7F), in male truncate (Fig. 9F). Ventrite 6 rounded in both sexes.

Male terminalia. Tegmen (Figs 4A, B, 8A, B, 10A, B) symmetrical; parameres articulated with penis guide. Penis (Figs 4C, 8C, 10C) slender, pointed apically; penis capsule asymmetrical with outer arm reduced, inner arm well developed. Apodeme of 
male sternum IX simple, not broadened apically (Figs 8D, 10D). Tergite X broadly rounded, semicircular (Figs 8D, 10D).

Female terminalia. Coxites (Figs 10F) distinctly elongate, subtriangular; styli small but visible, bearing several short setae; infundibulum absent (Figs 4D, 8E, 10E); sperm duct simple. Spermatheca (Figs 4D, 8E, 10E) worm-like, without clear ramus or nodulus; spermathecal accessory gland small, elongate. Proctiger elongate, rounded apically (Fig. 10F).

Immature stages. Larva as in Fig. 1A, pupa as in Fig. 1B.

Distribution. Holarctic: Asia, Europe, Africa (North), North America.

\section{Key to species of Coccidula Kugelann}

1 Head and epipleurae black (Fig. 1C, D); elytra with humeral area black. Nearctic C. lepida LeConte

- Head and epipleurae testaceous; elytra with humeral area testaceous. Palaearctic... 2

2 Pronotum with posterior corners pointed, with an angle much less than $90^{\circ}$ (Figs $1 \mathrm{G}, 3 \mathrm{~B}$ ); pronotal lateral margins broadly explanate (Figs 1E, 3B); prosternal process without carinae (Fig. 3C); elytra with missing or reduced rows of large punctures 2 and 3 (counted from the suture)

C. litophiloides Reitter

- Pronotum with posterior corners not distinctly pointed, with an angle around $90^{\circ}$ (Figs 1F-H, 7B, 9B); pronotal lateral margins moderately explanate (Figs 1G, 7B, 9B); prosternal process with distinct lateral carinae (Figs 7C, 9E); elytra with all rows of large punctures well visible.

3 Prosternal process with lateral carinae very distinct, sinuate, roundly joined to the anterior prosternal margin (Fig. 9E); lateral elytral margins in basal part not visible from above (Fig. 9A); metaventral postcoxal lines narrowly separated on metaventral process (Fig. 9D); specimens entirely testaceous or with more than one black macula on elytra (Fig. $1 \mathrm{H})$; penis guide about half length of parameres (Fig. 10A) C. scutellata Herbst

- Prosternal process with lateral carinae straight, sometimes not joined together, extending to level of anterior border of procoxal cavity, not merged to anterior prosternal margin (Figs 5C, 7C); lateral elytral margins in basal part visible from above (Figs 5A, 7A); metaventral postcoxal lines joined on metaventral process (Figs 5D, 7E); specimens entirely testaceous to rufous (Fig. 1G) or with single elongate dark brown to black macula near the elytral suture around middle of elytra (Fig. 1F); penis guide longer than parameres (Figs 6B, 8A) ..................4

4 Body entirely rufous, sometimes with darker scutellar shield (Fig. 1G); penis guide distinctly curved in lateral view, parameres at base about as broad as in middle (Fig. 8B)

C. rufa (Herbst)

- Body testaceous with small transverse macula at base of pronotum just above scutellar shield, scutellar shield dark, elytra with single dark brown to black, longitudinal macula on elytral suture around middle of elytra (Fig. 1F); penis guide mildly curved in lateral view, parameres at base distinctly narrower than in middle (Figs 6A, C) C. reitteri Dodge 


\section{Coccidula lepida LeConte, 1852}

Figs 1C, D, 2A-E

Coccidula lepida LeConte, 1852: 132.

Coccidula occidentalis Horn, 1895: 114.

Coccidula suturalis Weise, 1895: 132.

Material examined. United States of America: America b., 82, coll. Růžička et Vokál, (1: NMP); Alaska, Mi.1249, Alaska Hwy., Dedman Lk., 6.-7.VII.1968, Campbell \& Smetana (1: NMP); Vermont, Korschefsky det. (2: MIZ); Canada: SK, Harris Reservoir, Hwy 21, 10 km S, Maple Creek, April 19 2016, drift D. Larson (1 female: NMP). Type material not studied, deposited in Museum of Comparative Zoology, Cambridge, USA.

Diagnosis. Coccidula lepida is the only Nearctic species of the genus, and is similar in many characters to C. scutellata, but with the head and epipleura black. In the typical form (C. lepida described by LeConte), the black elytral pattern resembles an extension of the five fused black maculae on the elytra of C. scutellata, with shoulders and epipleura black. Shoulder tubercle distinct, prototum relatively narrow. Male genitalia with penis guide much shorter than parameres. Detailed description of morphology including variability in pattern can be found in Gordon (1985: 656-659).

Description. Length $=2.7-3.5 \mathrm{~mm}, \mathrm{BL} / \mathrm{BW}=1.88-1.96, \mathrm{EL} / \mathrm{BW}=1.40-1.42$, $\mathrm{PW} / \mathrm{BW}=0.73$.

Body elongate (Fig. 1C), slightly widening in posterior part. Head black. Elytra of typical form, light testaceous with black pattern covering scutellar shield and surrounding portion of elytra through shoulders to lateral margins, covering about $60 \%$ of its anterior part; pair of maculae in posterior 3/4 of elytra near suture; in western population fused and connected to scutellar shield over suture. Ventral side (Fig. 1D) black with hypomera and ventrites 3-6 testaceous.

Head and pronotum covered with uniform small setiferous punctures arranged irregularly. Pronotum transverse, broadly rounded laterally, with lateral margin glabrous; pronotum covered with dense setiferous punctures. Posterior pronotal corners not produced (Fig. 2A). Prosternum with anterior margin with bordering line complete. Prosternal process with complete lateral carinae, joined roundly and merged with anterior border of pronotum (Fig. 2B).

Scutellar shield pentagonal, covered with dense setiferous punctures. Elytra (Fig. 2D) covered with two types of punctures, small setiferous punctures irregularly distributed throughout the elytral surface, some of these punctures surrounded by larger depressed circles forming nine irregular longitudinal rows along the whole length of elytra. Shoulder tubercles distinct, but lateral elytral margin of elytra visible from above throughout. Mesoventrite (Fig. 2C) with anterior border interrupted in median part. Metaventrite (Fig. 2C) with postcoxal lines transverse in median part and then descending laterally, continuous on the metaventral process in median part; covered with setiferous punctures very sparsely distributed in central part of sclerite, densely 


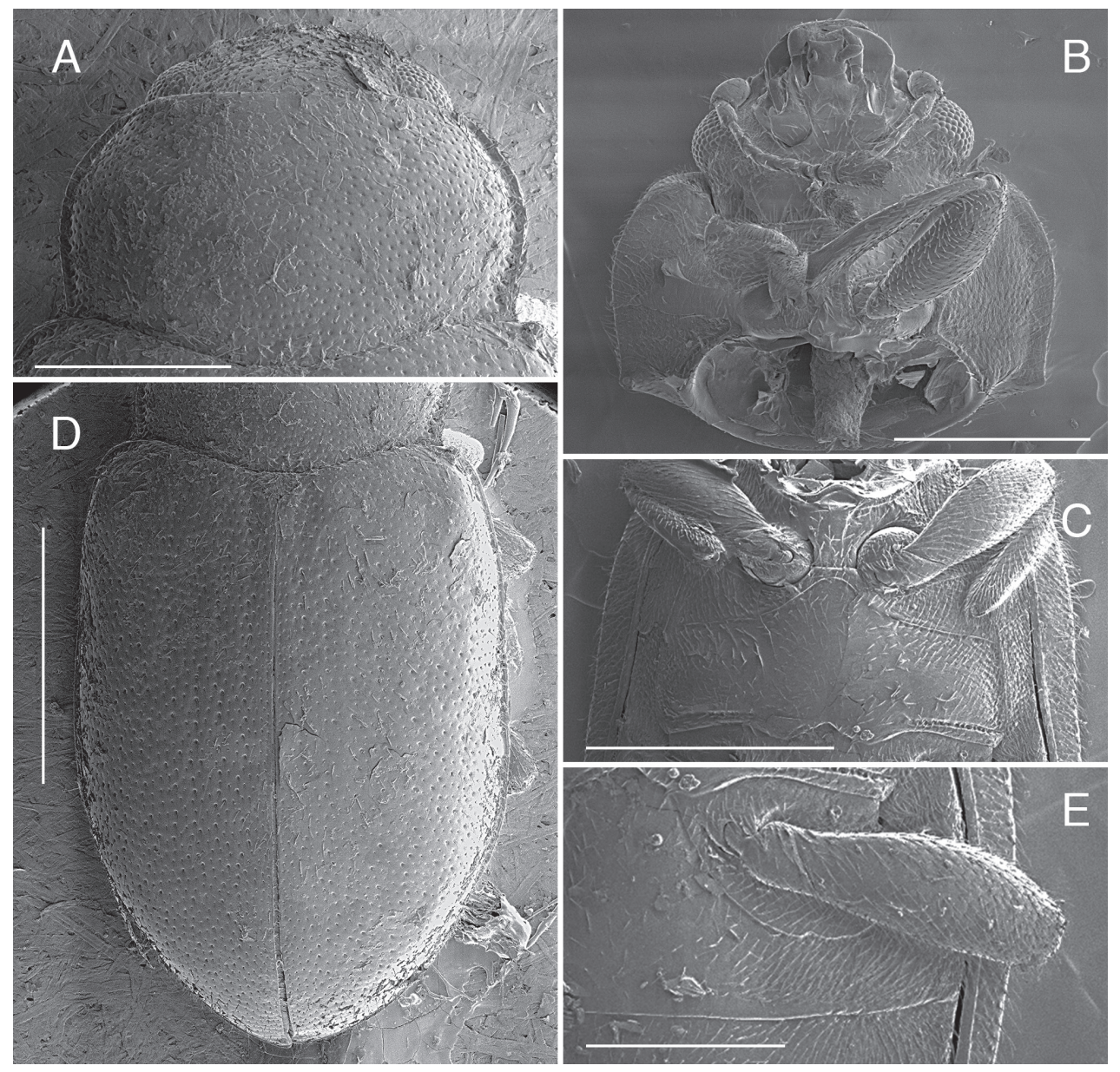

Figure 2. Coccidula lepida LeConte SEM illustrations A pronotum B head and prothorax, ventral C meso and metaventrite $\mathbf{D}$ elytra dorsal $\mathbf{E}$ ventrite 1 . Scale bars: $500 \mu \mathrm{m}(\mathbf{A}-\mathbf{C}) ; 1 \mathrm{~mm}(\mathbf{E}, \mathbf{D})$.

setose in anterolateral parts, with a single row of large punctures below postcoxal lines and above metacoxae.

Abdominal postcoxal lines (Fig. 2E) complete, widely rounded, reaching about half of the length of the ventrite 1 measured below metacoxa. Ventrites covered with dense setiferous punctures.

Male genitalia. Tegmen in inner view with penis guide subtriangular with pointed apex; short, about two times shorter than parameres. Parameres elongate elliptical, inner surface smooth, with long setae on the inner side and in apical margin. Penis simple with pointed apex. [see Gordon 1985: 657, fig. 539 a-d]

Female genitalia. Sperm duct long, much longer than length of spermatheca. Spermatheca vermiform, broadest in basal part. [see Gordon 1985: 657, fig. 539e]

Type locality. Vermont (USA).

Distribution. North part of North America. 


\section{Coccidula litophiloides Reitter, 1890}

Figs 1E, 3A-E, 4A-D

Coccidula litophiloides Reitter, 1890: 176

Lithophilus naviauxi Duverger, 1983: 83. syn. nov.

Material examined. Holotype. Azerbaijan, "Caucasus Araxesthal Leder Reitter/ Coll. Reitter/ Coccidula litophiloides 1890/ Holotypus 1890 Coccidula litophiloides Reitter", male (HNHM) (Fig. 11C). Holotype of L. naviauxi, Iran, Vannae, 30-V-77, leg. M. Rapilly, female (MNHN). Paratypes of C. litophiloides. Data same as for the holotype, (7: HNHM). Paratypes of L. naviauxi: Iran, Daran, 9-VI-77, M. Rapilly leg. (2 females: MNHN) (Figs 11A, B). Other material. Armenia, Eczmiadzin Cauc, 22 IV 1946, 6399, W. Eichler (2: MIZ); Jerevan město, Razdan, 26-27.5.1988, J. Strejček lgt., (1 male, 1 female: NMP); Iran, Lorestan, 1.1960 leg. A. Warchałowski (1: AJC); Iran, Khorramabad, 19-V-77, M. Rapilly leg. (1: MNHN).

Diagnosis. Coccidula litophiloides is very distinctive among Coccidula species with large produced posterior pronotal angles, and a prosternal process without carinae (which are present in all remaining species). With its general body shape slightly widening posteriorly and pronotum distinctly widened laterally with broad lateral bead appearing glabrous, it is similar to C. scutellata. Male genitalia are distinctive with large, elliptical parameres possessing projections on their inner surfaces, which is also unique among Coccidula. Spermatheca, in female genitalia, is distinctly widening apically and has a very short sperm duct, about $1 / 4$ of the length of spermatheca.

Description. Length $3.0-3.5 \mathrm{~mm}, \mathrm{BL} / \mathrm{BW}=1.95-1.97, \mathrm{EL} / \mathrm{BW}=1.32-1.40$, $\mathrm{PW} / \mathrm{BW}=0.81$.

Body elongate, slightly widening in posterior part. Dorsal and ventral side yellow to testaceous (Fig. 1E).

Head and pronotum covered with uniform small setiferous punctures arranged irregularly. Pronotum transverse, broadly rounded laterally (Figs 1E, 3B), with broad, glabrous lateral margin, covered with dense setriferous punctures, with a single row of larger punctures along lateral border. Posterior pronotal corner large, distinctly pointed (Fig. 3B). Prosternum with complete anterior bordering line. Prosternal process without lateral carinae (Fig. 3C).

Scutellar shield pentagonal, covered with dense setiferous punctures. Elytra covered with two types of punctures, small setiferous punctures irregularly distributed throughout elytral surface, some of these punctures surrounded by larger depressed circles, forming irregular longitudinal rows; rows 2 and 3 reduced or missing (Fig. 3A). Elytra more flattened in lateral view than in other Coccidula, without shoulder tubercle, lateral elytral margin visible throughout (Fig. 3A). Hind wings missing. Mesoventrite with anterior border complete. Metaventrite with postcoxal lines transverse, descending only laterally, fused on metaventral process in median part, forming continuous arc 

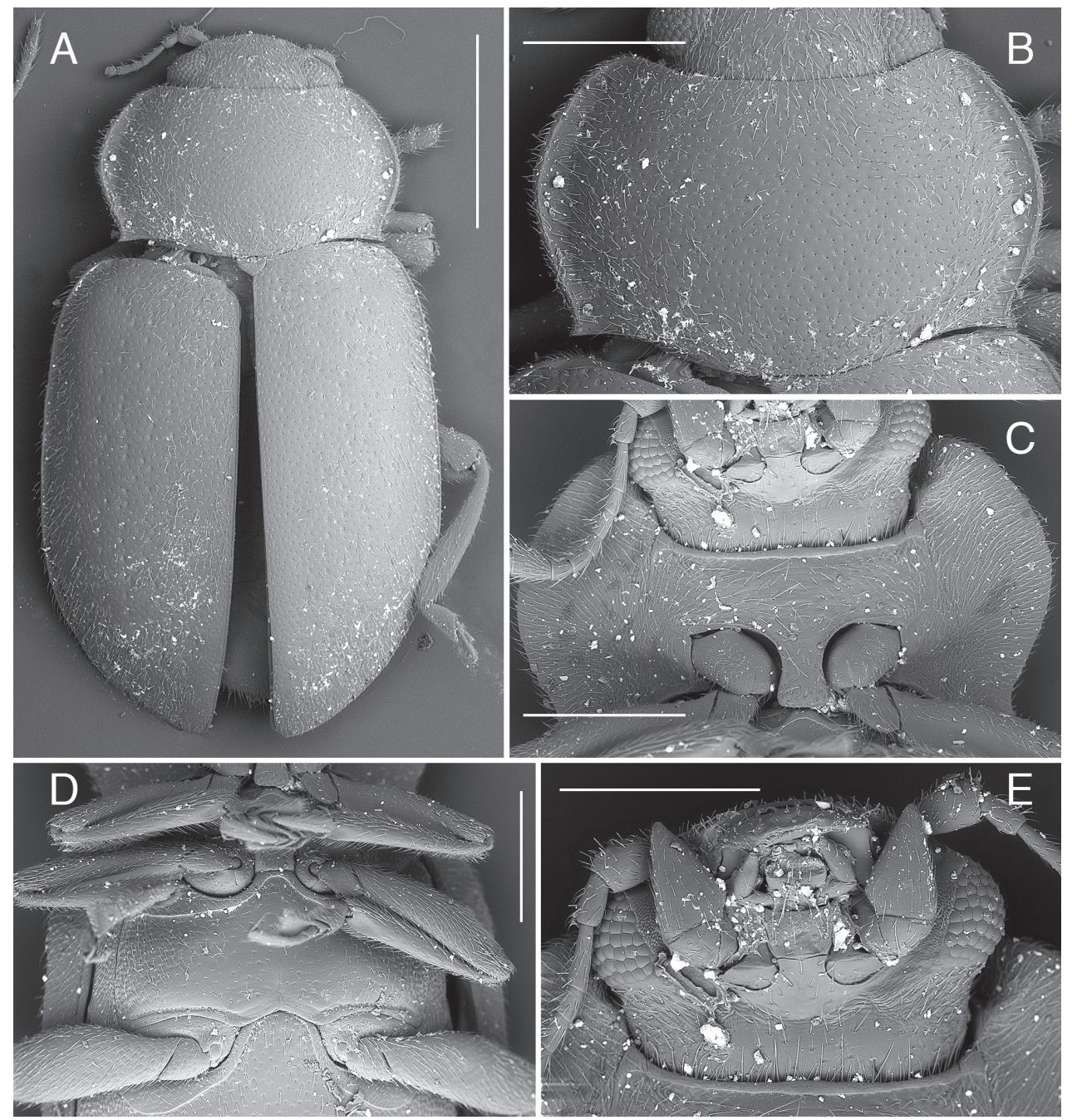

Figure 3. Coccidula litophiloides Reitter SEM illustrations, paratype HNHM A body, dorsal B pronotum C head and prothorax, ventral D meso and metaventrite $\mathbf{E}$ head ventral. Scale bars: $1 \mathrm{~mm}(\mathbf{A}) ; 500 \mu \mathrm{m}$ (B-D); $400 \mu \mathrm{m}$ (E).

(Fig. 3D); covered with setiferous punctures very sparsely distributed in central part of sclerite, densely setose in lateral parts, without distinct rows of large punctures below postcoxal lines, large punctures above metacoxae present.

Abdominal postcoxal lines complete, rounded, reaching slightly less than half of length of the ventrite 1 measured below metacoxa. Ventrites covered with dense setiferous punctures.

Male genitalia. Tegmen in inner view with penis guide pentagonal with pointed apex (Fig. 4B); short, slightly longer than half length of parameres (Fig. 4A). Parameres 


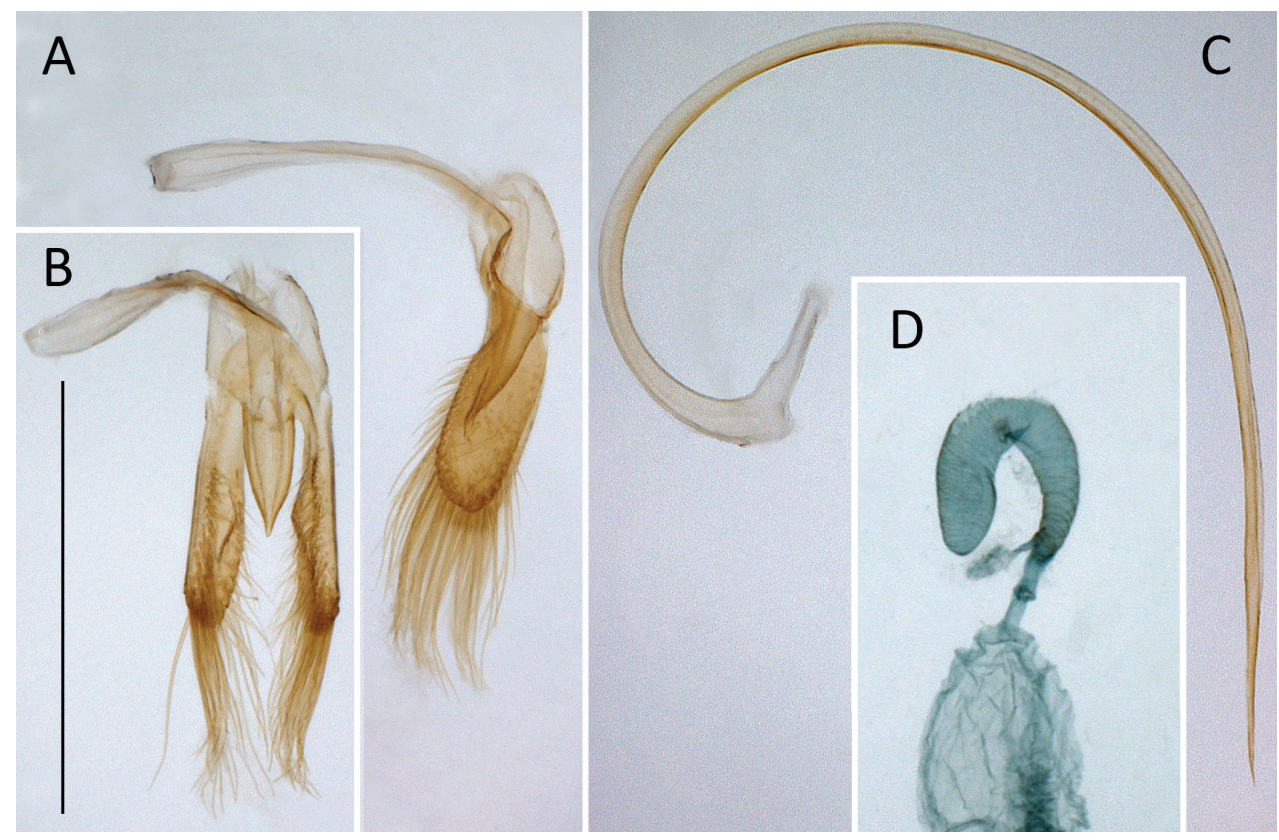

Figure 4. Coccidula litophiloides Reitter $\mathbf{A}$ tegmen, lateral $\mathbf{B}$ tegmen, inner $\mathbf{C}$ penis, lateral $\mathbf{D}$ spermatheca. Scale bar: $500 \mu \mathrm{m}(\mathbf{A}-\mathbf{D})$.

large, elliptical, inner surface with distinct projections (Fig. 4B), with fringe of long setae in apical margin. Penis simple with pointed apex (Fig. 4C).

Female genitalia. Sperm duct short (Fig. 4D), about as long as $1 / 4$ of spermatheca. Spermatheca vermiform, distinctly broadened apically. Accessory gland membranous, longer than sperm duct.

Type locality. Caucasus, Ordubad (Azerbaijan).

Distribution. Armenia, Azerbaijan, Iran

Remarks. Duverger (1983) described Lithophilus naviauxi from Iran. After examination of the type specimens (Fig. 1A, B) we noticed that this species does not belong to the genus Lithophilus Frölich (=Tetrabrachys Kapur). As drawn in the original publication (Duverger 1983), it has antennae with 11 antennomeres (10 in Tetrabrachys), and pseudotrimerous tarsi with tarsomere 3 very small and tarsomere 2 distinctly lobed, while in Tetrabrachys tarsi are distinctly tetramerous, with tarsomere 3 and 2 elongate, without distinct lobe. Duverger in his paper (1983) described L. naviauxi based on just three female specimens of which he illustrated the spermatheca (Duverger 1983: 89, figs 30, 31). However, C. litophiloides is also found in Iran. Comparison of the female genitalia of the type material of both taxa, and other available material, together with the lack of a second and third row of large punctures on the elytra, and other morphological features described in the original description of Duverger, led to the conclusion that $L$. naviauxi Duverger falls well within the definition of $C$. litophiloides; thus, we propose to synonymize both species. 


\section{Coccidula reitteri Dodge, 1938}

Figs 1F, 5A-E, 6A-C

Coccidula suturalis Reitter 1897: 127 nom. nud. (nec. C. suturalis Weise, 1895: 132). Coccidula reitteri Dodge, 1938: 222.

Material examined. Holotype. Russia, "Quell. d. Jrbut Reitter./ Transbaikal leg. Leder/ Coll. Reitter/ / Coccidula scutellaris m 1896/ Coccidula reitteri Dodge Khnzorian det./ prep. genital R. Bielawski 1956/ Holotypus 1897 Coccidula suturalis Reitter/ Photo ID: HNHM_COL_574”, female (HNHM). Other material. Russia, "Transbaikalien Leder Reitter/ Coccidula suturalis Rtt. Coll. Reitter/ Coccidula reitteri Dodge, det. Merkl 1984/ prep. genital R. Bielawski 1956" (1 male: HNHM); Listvjanka pr. Bajkal, step, 29.6.1977, H. Karnecka lgt. (1 male, 1 female: NMP).

Diagnosis. Coccidula reitteri is very similar to C. rufa in external appearance, however, it can be distinguished by the presence of a small black transverse macula on the pronotum just anterior to the scutellar shield, and a longitudinal brown to black macula on the posterior half of the elytra on the elytral suture. Male genitalia are very close to C. rufa, however, the upper margin of the penis guide in lateral view is relatively less emarginated and parameres are narrower than in C. rufa.

Description. Length $=2.8-3.2 \mathrm{~mm}, \mathrm{BL} / \mathrm{BW}=1.85-1.90, \mathrm{EL} / \mathrm{BW}=1.33, \mathrm{PW} /$ $\mathrm{BW}=0.77$.

Body elongate, parallel sided (Fig. 5A). Pronotum (Fig. 1F) with black transverse macula in front of the scutellar shield. Scutellar shield black. Elytra brown with elongate, dark brown to black macula along the elytral suture in posterior half. Ventral side testaceous with prosternum, mesoventrite, metaventrite, most of the ventrite 1 (except lateral corners), and central part of ventrite 2 black.

Head and pronotum covered with uniform small setiferous punctures arranged irregularly. Pronotum (Fig. 5B) transverse, broadly rounded laterally, with moderately broad, lateral margin without glabrous area; pronotum covered with dense setriferous punctures, with single row of larger punctures along lateral border. Posterior pronotal corners not produced (Fig. 5B). Prosternum with anterior margin with bordering line incomplete in median part, without small sub-rounded impression in center. Prosternal process with lateral carinae straight, joined together roundly at level of anterior border of procoxae, forming sub-triangular pattern (Fig. 5C).

Scutellar shield pentagonal, covered with dense setiferous punctures. Elytra covered with two types of punctures, small setiferous punctures irregularly distributed throughout the elytral surface, some of these punctures surrounded by larger depressed circles forming nine irregular longitudinal rows along whole length of elytra. Lateral elytral margin well visible throughout (Fig. 5A). Mesoventrite with complete anterior border. Metaventrite with postcoxal lines descending laterally, fused on metaventral process in median part, forming continuous arc (Fig. 5D); covered with setiferous punctures very sparsely distributed in central part of sclerite, densely setose in lateral parts, without distinct rows of large punctures below postcoxal lines, large punctures above metacoxae present. 



Figure 5. Coccidula reitteri Dodge SEM illustrations, HNHM A body, dorsal B pronotum C head and prothorax, ventral D meso and metaventrite $\mathbf{E}$ antenna. Scale bars: $1 \mathrm{~mm}(\mathbf{A}) ; 500 \mu \mathrm{m}(\mathbf{B}-\mathbf{D}) ; 300 \mu \mathrm{m}(\mathbf{E})$.

Abdominal postcoxal lines complete, arcuate, reaching half of length of ventrite 1 measured below metacoxa. Ventrites covered with sparse setiferous punctures.

Male genitalia. Tegmen in inner view (Fig. 6B) with penis guide broadly rounded in the median or apical part, with rounded apex; in lateral view (Fig. 6C) moderately expanded medially, with upper surface moderately emarginate; long, much longer than parameres. Parameres elongate, parallel sided, with narrow base, inner surface smooth, with fringe of long setae in apical part. Penis simple with pointed apex, with small bump before apex.

Female genitalia. Spermatheca vermiform, not distinctly broadened apically (Fig. 6A).

Type locality. Mongolia, Russia (Krasnoyarsk region, Irkutsk region, Tuva) 


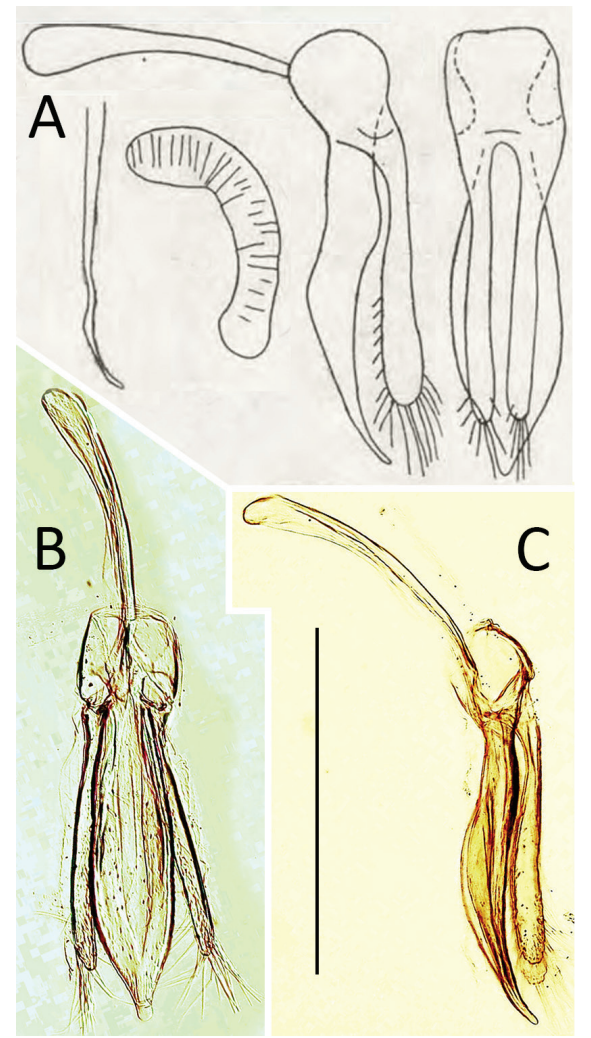

Figure 6. Coccidula reitteri Dodge $\mathbf{A}$ original drawings of male and female genitalia by Bielawski 1984 B tegmen, inner $\mathbf{C}$ tegmen, lateral. Scale bar: $500 \mu \mathrm{m}(\mathbf{B}, \mathbf{C})$.

Distribution. Russia (East Siberia).

Remarks. Coccidula reitteri is very similar to C. rufa in external morphological characters as well as the structure of male and female genitalia (Fig. 6A) (Bielawski 1984); thus, further investigation, preferably of molecular markers, should be conducted to confirm whether it is a separate species or an eastern population of C. rufa.

\section{Coccidula rufa (Herbst, 1783)}

Figs 1A, B, G, 7A-F, 8A-E

Dermestes rufus Herbst, 1783: 22.

Chrysomela pectoralis Fabricius, 1792: 328.

Silpha rosea Marscham, 1802: 123.

Coccidula conferta Reitter, 1890: 176.

Coccidula rufa var. unicolor Reitter, 1890: 176.

Coccidula rufa var. nigropunctata Reitter, 1900: 220. 
Coccidula rufa var. plagiata Gerhardt, 1910: 556.

Material examined. Czech Rep., Zlín, 11.6.1999, lgt. L. Bureš (1: NMP); Mladá Boleslav, 25.4.1987, lgt. Nedvěd (1 male USB); Dvořiště, 9.8.1989, lgt. Nedvěd (1: USB); Kokořínský důl, 9.8.1995, lgt. J. Řehounek (1: USB); Kyrgyzstan, Toktogul, 26 VI 2003, leg. A. Lasoń, WJ 2870, (1 male: AJC); Montenegro, Skadar jez.- Virpazar, 5.6.1984, J. Strejček lgt. (1: NMP); Poland, Kampinos Forest near Warsaw, 17.06.2020, leg. D. Marczak, (7: MIZ); Russia, Leningrad-Lachta, IX 1988, J. Strejček lgt., (1: NMP); Ukraine, Kharkiv region, Dergachevsky district, Boliboki vill., 50 $9^{\prime} 16.57^{\prime \prime N}, 36^{\circ} 3^{\prime} 58.87^{\prime E}$, 1.5.2017, lgt. A. Slutsky (1: ASC); Uzbekistan, Buchara/ Coccidula unicolor Rtt./ Coll. Reitter/ MIZ PAN Warszawa 27/1955/1 (1: MIZ). Type material not studied, deposited in Museum für Naturkunde, Berlin, Germany.

Diagnosis. Coccidula rufa is most similar in external appearance to C. reitteri, however it can be separated by the uniform testaceous coloration of the dorsal surface (C. reitteri possesses dark macula near the elytral suture). From uniformly colored specimens of C. scutellata it can be separated by the shape of carinae on the prosternal process. Male genitalia are also very distinctive: in C. scutellata penis guide is small, about half length of parameres, while in C. rufa it is longer than parameres. Spermatheca in female genitalia of $C$. rufa is vermiform, not widening apically, while in C. scutellata it is distinctly widened in apical part.

Description. Length $=2.5-3.2 \mathrm{~mm}, \mathrm{BL} / \mathrm{BW}=1.88-2.00, \mathrm{EL} / \mathrm{BW}=1.38-1.44$, $\mathrm{PW} / \mathrm{BW}=0.80-0.82$.

Body elongate, parallel sided. Elytra of typical (European) form testaceous without maculae (Fig. 1G), only scutellar shield dark brown to black. Ventral side testaceous with prosternal process, mesoventrite, metaventrite, most of the ventrite 1 (except lateral corners), and central part of ventrite 2 black.

Head and pronotum covered with uniform small setiferous punctures arranged irregularly. Pronotum transverse, broadly rounded laterally, with moderately broad, lateral margin without glabrous area (Fig. 7B); pronotum covered with dense setiferous punctures, with a single row of larger punctures along lateral border. Posterior pronotal corners not produced (Fig. 7B). Prosternum with anterior margin with incomplete bordering line in median part, with a small sub-rounded impression in center. Prosternal process with lateral carinae straight, joined together roundly at level of anterior border of procoxae, forming sub-triangular pattern (Fig. 7C).

Scutellar shield pentagonal, covered with dense setiferous punctures. Elytra covered with two types of punctures, small setiferous punctures irregularly distributed throughout elytral surface, some of these punctures surrounded by larger depressed circles forming nine irregular longitudinal rows along whole length of elytra. Lateral elytral margin well visible throughout (Fig. 7A). Mesoventrite with complete anterior border. Metaventrite with postcoxal lines descending laterally, fused on metaventral process in median part, forming continuous arc (Fig. 7E), covered with setiferous punctures very sparsely 


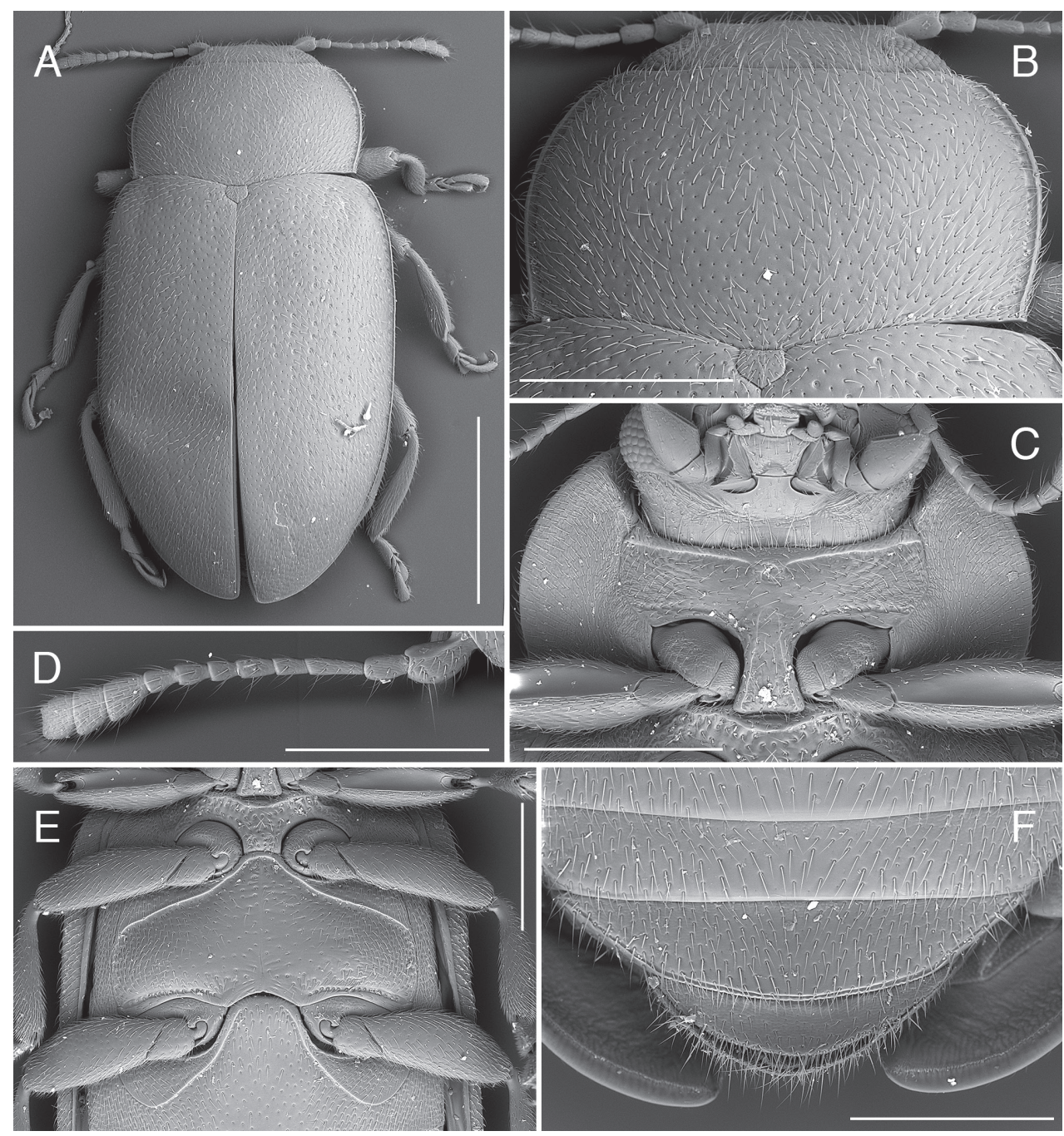

Figure 7. Coccidula rufa (Reitter) SEM illustrations $\mathbf{A}$ body, dorsal B pronotum $\mathbf{C}$ head and prothorax, ventral $\mathbf{D}$ antenna $\mathbf{E}$ mesoventrite, metaventrite and ventrite $1 \mathbf{F}$ ventrites 4-6, female. Scale bars: $1 \mathrm{~mm}(\mathbf{A})$; $500 \mu \mathrm{m}(\mathbf{B}, \mathbf{C}, \mathbf{E}, \mathbf{F}) ; 400 \mu \mathrm{m}(\mathbf{D})$.

distributed in central part of sclerite, densely setose in lateral parts, without distinct rows of large punctures below postcoxal lines, large punctures above metacoxae present.

Abdominal postcoxal lines complete, arcuate, reaching half of length of ventrite 1 measured below metacoxa. Ventrites covered with sparse setiferous punctures.

Male genitalia. Tegmen in inner view (Fig. 8A) with penis guide sub-parallel to broadly rounded, with rounded apex; in lateral view (Fig. 8B) expanded medially, with deeply emarginated upper margin; long, much longer than parameres. Parameres elongate, parallel sided, with just slightly narrower base, inner surface smooth, with fringe 


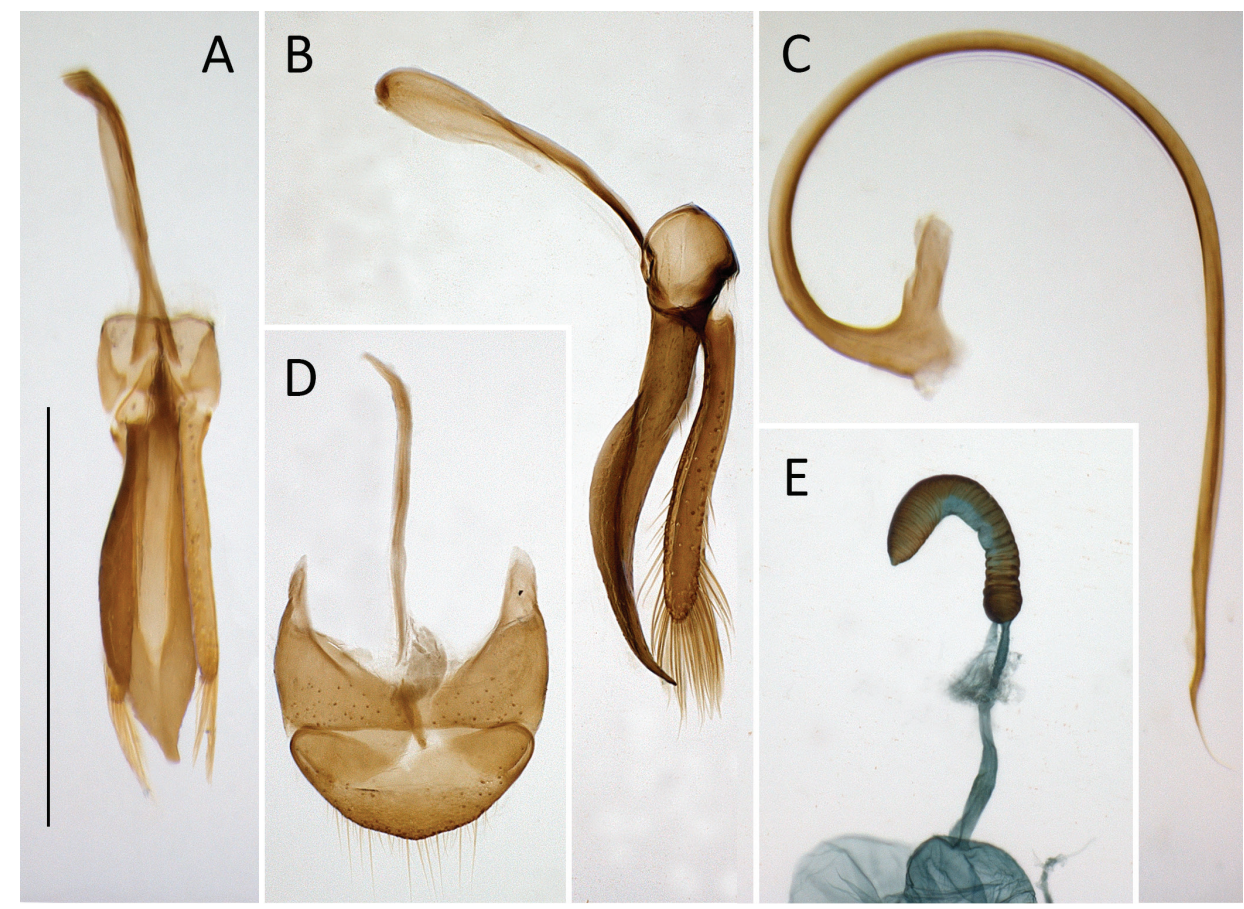

Figure 8. Coccidula rufa (Reitter) $\mathbf{A}$ tegmen, inner $\mathbf{B}$ tegmen, lateral $\mathbf{C}$ penis, lateral $\mathbf{D}$ male genital segment, dorsal E spermatheca. Scale bar: $500 \mu \mathrm{m}(\mathbf{A}-\mathbf{E})$.

of long setae in apical part. Penis simple with sharply pointed and curved apex, with small bump before apex (Fig. 8C).

Female genitalia. Sperm duct long, longer than spermatheca (Fig. 8E). Spermatheca vermiform, not distinctly broadened apically. Accessory gland membranous, much shorter than sperm duct.

Type locality. Berlin (Germany)

Distribution. Europe (all countries), Africa: Morocco, Asia: Afghanistan, China, Russia (Siberia), Iran, Kazakhstan, Kyrgyzstan, Mongolia, Turkey, Uzbekistan.

\section{Coccidula scutellata (Herbst, 1783)}

Figs 1H, 9A-G, 10A-I

Chrysomela scutellata Herbst, 1783: 58.

Nitidula quinquepunctata Fabricius, 1787: 52.

Silpha melanophthalma Gmelin, 1790: 1627.

Nitidula bipunctata Gmelin, 1790: 1630

Coccidula scutellata: Kugelann 1798: 421.

Coccidula scutellata var. subrufa Weise, 1879: 131.

Coccidula scutellata var. arquata Weise, 1879: 131. 
Coccidula scutellata var. aethiops Krauss, 1902: 92.

Material examined. Armenia, Erevan, 9.06.1987, leg. V. Karasjov (5: AJC); Czech ReP., Praha-Kyje, 21.1.1945, lgt. Günnther, (1: NMP); Plzeň, 20.7.1978, lgt. V. Mach, (2: USB); Kokořínský důl, 28.8.1994, lgt. J. Řehounek (1: USB); Loučeň, 17.8.1994, lgt. J. Řehounek (1: USB); France, St. Cucufa, VI 65, MD, Ch. 'Duverger det., J.P. Coutanceau det. 2004' (1: MNHN); Poland, Kampinos Forest near Warsaw, 17.06.2020, leg. D. Marczak (11: MIZ); SlovaKia, Bratislava, 27.4.36, lgt. O. Kavan (1: NMP); Ukraine, Kharkiv region, Kharkiv district, Bobrovka vill., reserve "Aleshkina balka", 2017-04-28, lgt. A. Slutsky (1: ASC). Type material not studied, deposited in Museum für Naturkunde, Berlin, Germany.

Diagnosis. Coccidula scutellata is the most variable species in body coloration. Typical forms with five black maculae on the elytra can be easily distinguished from other Coccidula species, however uniformly colored testaceous forms are externally similar to C. rufa. They can be easily distinguished by the shape of carinae on prosternal process, which are straight and form a sub-triangular pattern in C. rufa, and are sinuate and broadly rounded apically, and fused with anterior border of prosternum in C. scutellata. Moreover, C. scutellata has a more distinct shoulder tubercle, and relatively narrower protnotum. Also, the male genitalia are distinctive, with penis guide longer than parameres in C. rufa and much shorter in C. scutellata. Spermatheca, in female genitalia, is broadened apically in C. scutellata, while in C. rufa it is almost uniform in diameter.

Description. Length $=2.8-4.2 \mathrm{~mm}, \mathrm{BL} / \mathrm{BW}=1.85-2.05, \mathrm{EL} / \mathrm{BW}=1.36-1.46$, $\mathrm{PW} / \mathrm{BW}=0.70-0.75$.

Body elongate, slightly widening in posterior part. Elytra of typical (European) form testaceous with five black maculae (Fig. 1H), one large covering scutellar shield and surrounding portion of elytra, and four sub-oval maculae in the median part, two of which are placed close to elytral suture and remaining two, close to lateral margin. Sometimes macula surrounding scutellar shield extends along elytral suture, sometimes maculae placed in median part of elytra are fused, forming single band. Various forms with reductions of this pattern are also present to completely testaceous forms without any trace of black color. Ventral side testaceous with prosternal process, mesoventrite, metaventrite, most of ventrite 1 (except lateral corners), and central part of ventrite 2 black.

Head and pronotum covered with uniform small setiferous punctures arranged irregularly. Pronotum transverse, broadly rounded laterally, with broad, glabrous lateral margin (Fig. 9B); pronotum covered with dense setiferous punctures, with single row of larger punctures along lateral border. Posterior pronotal corners not produced. Prosternum with anterior margin with bordering line complete. Prosternal process with complete lateral carinae in form of sinuate line, joined roundly and merged with anterior border of pronotum (Fig. 9E).

Scutellar shield pentagonal, covered with dense setiferous punctures. Elytra covered with two types of punctures, small setiferous punctures irregularly distributed throughout elytral surface, some of these punctures surrounded by larger depressed circles forming nine irregular longitudinal rows along whole length of elytra. Shoulder 


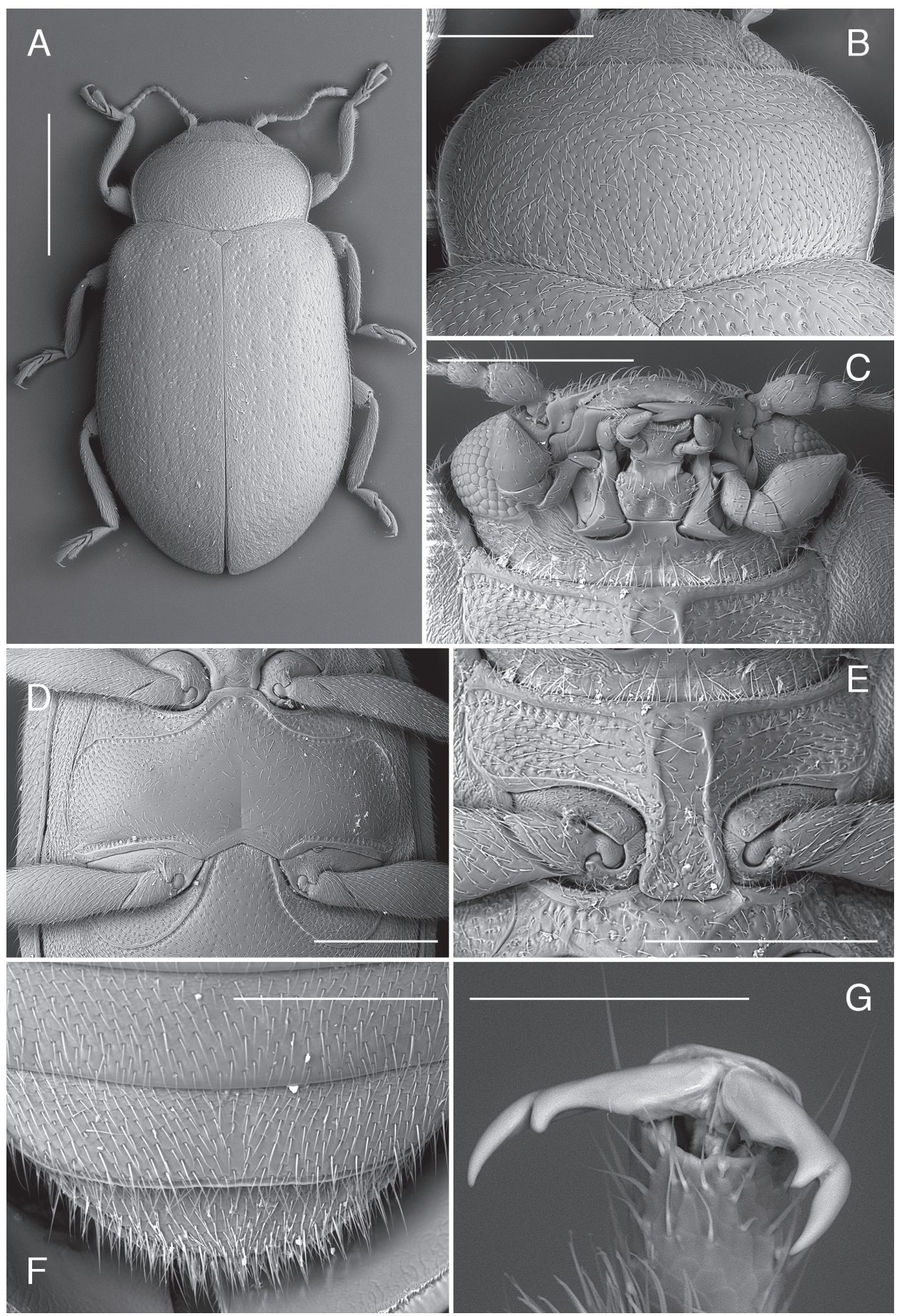

Figure 9. Coccidula scutellata (Reitter) SEM illustrations $\mathbf{A}$ body, dorsal B pronotum $\mathbf{C}$ head, ventral $\mathbf{D}$ mesoventrite, metaventrite and ventrite $1 \mathbf{E}$ prosternum $\mathbf{F}$ ventrites $4-6$, male $\mathbf{G}$ pro-tarsal claw. Scale bars: $1 \mathrm{~mm}(\mathbf{A}) ; 500 \mu \mathrm{m}(\mathbf{B}, \mathbf{D}, \mathbf{E}) ; 400 \mu \mathrm{m}(\mathbf{C}, \mathbf{F}) ; 100 \mu \mathrm{m}(\mathbf{G})$. 


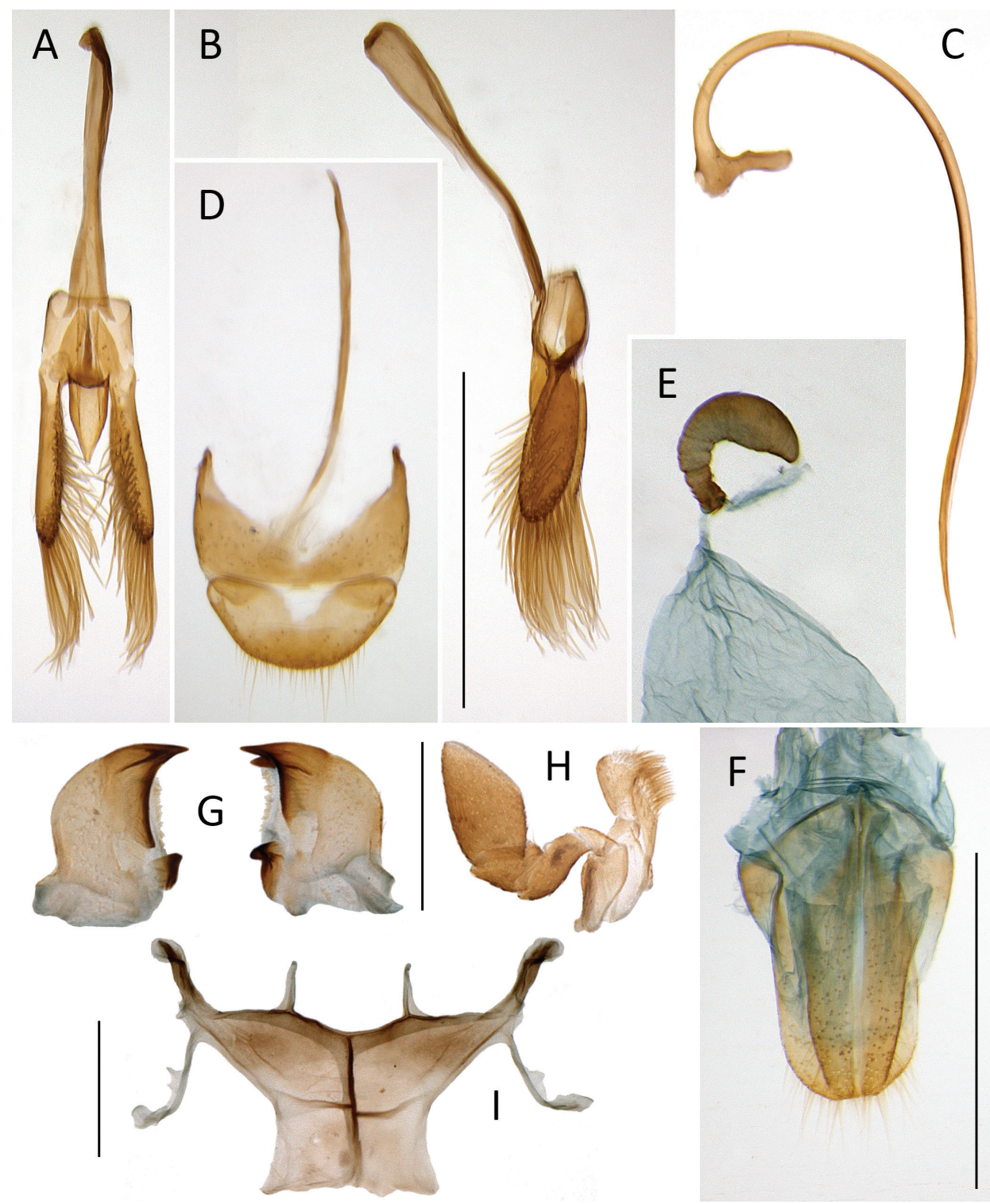

Figure 10. Coccidula scutellata (Reitter) A tegmen, inner B tegmen, lateral C penis, lateral D male genital segment, dorsal $\mathbf{E}$ spermatheca $\mathbf{F}$ female genitalia $\mathbf{G}$ left and right mandibles $\mathbf{H}$ maxilla $\mathbf{I}$ metendosternite. Scale bars: $500 \mu \mathrm{m}(\mathbf{A}-\mathbf{F}) ; 200 \mu \mathrm{m}(\mathbf{G}-\mathbf{I})$.

tubercles distinct, lateral elytral margin of elytra not visible from above in anterior part (Fig. 9A). Mesoventrite with anterior border interrupted in median part. Metaventrite with postcoxal lines transverse in median part and then descending laterally, not fused on metaventral process in median part (Fig. 9D). Covered with setiferous punctures very sparsely distributed in central part of sclerite, densely setose in lateral parts, with single row of large punctures below postcoxal lines and above metacoxae. 

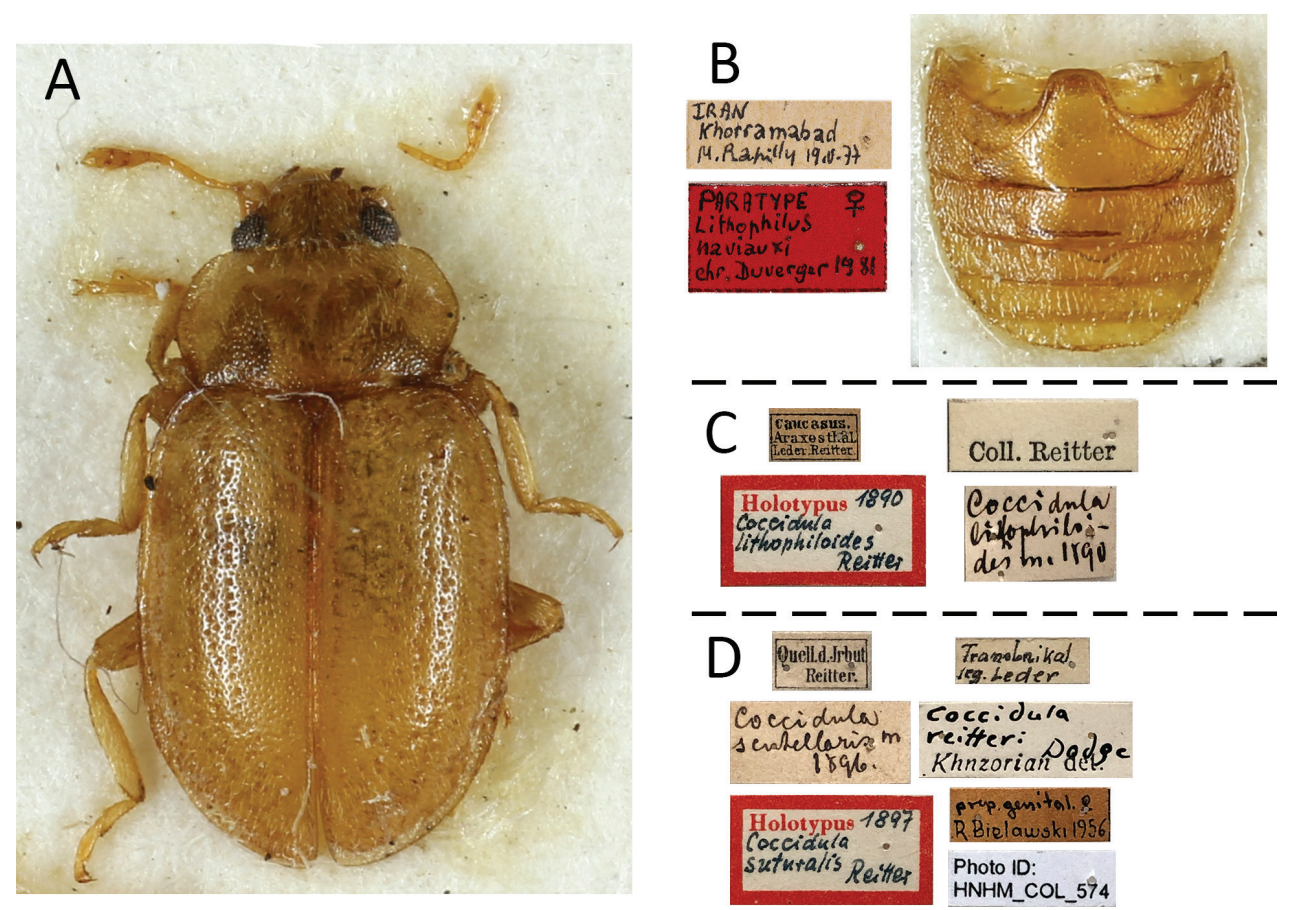

Figure I I. Lithophilus naviauxi Duverger A paratype MNHN, dorsal B paratype labels and abdomen C Coccidula litophiloides Reitter, holotype labels D Coccidula suturalis Reitter, holotype labels.

Abdominal postcoxal lines complete, rounded, reaching slightly more than half of length of ventrite 1 measured below metacoxa. Ventrites covered with dense setiferous punctures.

Male genitalia. Tegmen in inner view (Fig. 10A) with penis guide subtriangular with pointed apex; short, about two times shorter than parameres. Parameres elongate elliptical (Fig. 10B), inner surface smooth, with long setae on inner surface and in apical margin. Penis simple with pointed apex (Fig. 10C).

Female genitalia. Sperm duct short, about as long as half of length of spermatheca (Fig. 10E). Spermatheca vermiform, distinctly broadened apically. Accessory gland membranous, longer than sperm duct.

Type locality. Pomerania (Germany, Poland)

Distribution. Europe (all countries), Africa: Morocco, Asia: Kazakhstan, Russia (West Siberia).

\section{Acknowledgements}

We thank Otto Merkl and Tamás Németh (HNHM), Andrzej Jadwiszczak (Olsztyn, Poland), Lukáš Sekerka (NMP) and Alexander Slutsky (Kharkov, Ukraine) for a loan of specimens used in this study. Dawid Marczak (Warsaw, Poland) is thanked for providing fresh specimens of European Coccidula for analyses. Magdalena Kowalewska- 
Groszkowska (MIZ) is acknowledged for her help with the SEM illustrations, and Biology Centre CAS - The Laboratory of Electron Microscopy for making part of SEM images. Danny Haelewaters (USA), David Larson (USA), Vincent Nicolas (France), Gilles San Martin (Belgium) and Udo Schmidt (Germany) are acknowledged for providing habitus photos. The study was partially supported by grant number 20$10003 S$ provided by the Grant agency of Czech Republic to O. Nedvěd. The reviewer and the Editor are acknowledged for their valuable comments on the earlier version of this manuscript.

\section{References}

Bielawski R (1959) Chrząszcze - Coleoptera. Biedronki - Coccinellidae. Klucze do Oznaczania Owadów Polski, XIX 76: 1-92.

Bielawski R (1984) Coccinellidae (Coleoptera) of Mongolia. Annales Zoologici 38(14): 281-460. Che L, Zhang P, Deng S, Escalona HE, Wang X, Li Y, Pang H, Vandenberg N, Ślipiński A, Tomaszewska W, Liang D (2021) New insights into the phylogeny and evolution of lady beetles (Coleoptera: Coccinellidae) by extensive sampling of genes and species. Molecular Phylogenetics and Evolution Molecular Phylogenetics and Evolution 156: 107045. https://doi.org/10.1016/j.ympev.2020.107045

Clayhills T, Markkula M (1974) The abundance of coccinellids on cultivated plants. Annales Entomologicae Fennicae 40: 49-55.

Crotch GR (1874) A revision of the coleopterous family Coccinellidae. E. W. Janson, London, 311 pp. https://doi.org/10.5962/bhl.title.8975

Czerwiński T, Szawaryn K, Tomaszewska W (2020) Three new species of the genus Rhyzobius Stephens, 1829 from New Guinea (Coleoptera: Coccinellidae: Coccidulini). European Journal of Taxonomy 692: 1-17. https://doi.org/10.5852/ejt.2020.692

Dejean PFMA (1821) Catalogue de la collection de coléoptères de M. le Baron Dejean. Crevot, Paris, [viii +] 138 pp. https://doi.org/10.5962/bhl.title.11259

Dodge HR (1938) Coccidula suturalis synonymy (Coleop.: Coccinellidae). Entomological News and Proceedings of the Entomological Section of the Academy of Natural Sciences of Philadelphia 49: 221-222.

Duverger C (1983) Contribution à la connaissance des Coccinellidae d'Iran. Nouvelle Revue d'Entomologie, Nouvelle Série 13(1): 73-93.

Fabricius JC (1787) Mantissa insectorum sistens eorum species nuper detectas adiectis characteribus genericis, differentiis specificis, emendationibus, observationibus. Tom I. Hafhiae: Chist. Gottl. Profit, [xx +] 348 pp. https://doi.org/10.5962/bhl.title.36471

Fabricius JC (1792) Entomologia systematica emendata et aucta. Secundum classes, ordines, genera, species adjectis synonymis, locis, descriptionibus, observationibus. Tom I. Pars I. Hafhiae: Christ. Gottl. Proft, [xx +] 330 pp. https://doi.org/10.5962/bhl.title.122153

Fürsch H (2007) New species of Epipleuria Fürsch and Rhyzobius Stephens from southern Africa (Coleoptera: Coccinellidae: Coccidulini). Annals of the Transvaal Museum 44: 11-24.

Fürsch H (2001) Die Gattung Epipleuria gen. n. (Coleoptera, Coccinellidae, Coccidulinae). Mitteilungen der Münchner Entomologischen Gesellschaft 91: 5-33. 
Gerhardt J (1910) Neujeiten der schlesischen Kaferfauna aus dem Jahre 1909. (Col.). Deutsche Entomologische Zeitschrift 1910: 554-557. https://doi.org/10.1002/mmnd.4801910507 Gmelin JF (1790) Caroli a Linné Systema Naturae per regna tria naturae, secundum classes, ordines, genera, species, cum characteribus, differentiis, synonymis, locis. Editio decima tertia, aucta, reformata. Tomus I Pars IV. Classis V. Insecta. Lipsiae: Georg Enanuel Beer, 1517-2224.

Gordon R (1994) South American Coccinellidae (Coleoptera). Part IV: Definition of Exoplectrinae Crotch, Azyinae Mulsant, and Coccidulinae Crotch; a taxonomic revision of Coccidulini. Revista Brasileira de Entomologia 38(3/4): 681-775.

Gordon RD (1985) The Coccinellidae (Coleoptera) of America north of Mexico. Journal of the New York Entomological Society 93(1): 1-912.

Herbst JFW (1783) Kritisches Verzeichniss meiner Insektensammlung. Archiv der Insectengeschichte. Herausgegeben von Johann Caspar Füessly 4: 1-72.

Horn GH (1895) Studies in Coccinellidae. Transactions of the American Entomological Society 22: $81-114$.

Kirejtshuk AG, Nel A (2012) The oldest representatives of the family Coccinellidae (Coleoptera: Polyphaga) from the lowermost Eocene Oise amber (France). Zoosystematica Rossica 21: 131-144. https://doi.org/10.31610/zsr/2012.21.1.131

Kovář I (1996) Phylogeny. In: Hodek I, Honěk A (Eds) Ecology of Coccinellidae. Kluwer Academic Publishers, Dordrecht, 19-31. https://doi.org/10.1007/978-94-017-1349-8_2

Kovár I (2007) Coccinellidae. In: Löbl I, Smetana A (Eds) Catalogue of Palaearctic Coleoptera. Volume 4. Elateroidea, Derodontoidea, Bostrichoidea, Lymexyloidea, Cleroidea, Cucujoidea. Apollo Books, Stentrup, 71-74, 568-630.

Krauss H (1902b) Coleopterologische Beitrâge zur Fauna Austriaca. III. Wiener Entomologische Zeitung 21: 89-92.

Kugelann JG (1798) Verzeichniss der Käfer Preussens. Entworfen von Johann Gottlieb Kugelann Apotheker in Osterode. Ausgearbeitet von Johann Karl Wilhelm Illiger. Mit einer Vorrede von Hellwig und dem angehängten Versuch einer natürlichen Ordnung und Gattungsfolge der Insecten. Johann Jacob Gebauer, Halle, 500 pp. https://doi.org/10.5962/bhl. title. 125071

Lawrence JF, Ślipiński A, Seago A, Thayer M, Newton A, Marvaldi A (2011) Phylogeny of the Coleoptera based on adult and larval morphology. Annales Zoologici 61: 1-217. https:// doi.org/10.3161/000345411X576725

LeConte JL (1852) Remarks upon the Coccinellidae of the United States. Proceedings of the Academy of Natural Sciences of Philadelphia 6: 129-145.

Marsham T (1802) Entomologia Britannica, sistens insecta britanniae indigena, secundum methodum linnaeanam disposita. Tomus I. Coleoptera. Londini: Wilks et Taylor, J. White, [xxxi +] 548 pp. https://doi.org/10.5962/bhl.title.65388

Mulsant E (1846) Histoire Naturelle des coléoptěres de France. Sulcicolles - Sécuripalpes. Maison, Paris, [xxiv +] 280 pp.

Panzer GW (1813) Index Entomologicus sistens omnes Insectorum, Pars I. Eleutherata, 2016 pp. Poorani J, Ślipiński A (2009) A Revision of the Genera Scymnodes Blackburn and Apolinus Pope et Lawrence (Coleoptera: Coccinellidae). Annales Zoologici 59(4): 549-584. https://doi. org/10.3161/000345409X484946 
Reitter E (1890) Neue Coleopteren aus Europa und den angrenzenden Ländern und Sibirien, mit Bemerkungen über bekannte Arten. Deutsche Entomologische Zeitschrift 3: 145164. https://doi.org/10.1002/mmnd.48018900323

Reitter E (1897) Fünfzehnter Beitrag zur Coleopteren-Fauna des russischen Reiches. Wiener Entomologische Zeitung 16: 121-127. https://doi.org/10.5962/bhl.part.12846

Reitter E (1900) Neue, von Herrn John Sahlberg auf seinen Reisen in Corfu, Palästina und Zentral-Asien gesammelte Coleopteren. Wiener Entomologische Zeitung 19: 217-220. https://doi.org/10.5962/bhl.part.3455

Robertson JA, Ślipiński A, Moulton M, Shockley FW, Giorgi A, Lord NP, McKenna DD, Tomaszewska W, Forrester J, Miller KB, Whiting MF, McHugh J (2015) Phylogeny and classification of Cucujoidea and the recognition of a new superfamily Coccinelloidea (Coleoptera: Cucujiformia). Systematic Entomology 40(4): 745-778. https://doi.org/10.1111/ syen. 12138

Sasaji H (1968) Phylogeny of the family Coccinellidae (Coleoptera). Etizenia 35: 1-37.

Seago A, Giorgi JA, Li J, Ślipiński A (2011) Phylogeny, classification and evolution of ladybird beetles (Coleoptera: Coccinellidae) based on simultaneous analysis of molecular and morphological data. Molecular Phylogenetics and Evolution 60: 137-151. https://doi. org/10.1016/j.ympev.2011.03.015

Ślipiński A (2007) Australian ladybird beetles (Coleoptera: Coccinellidae): their biology and classification. Department of the Environment and Water Resources, Canberra, [xviii p] 288 pp.

Stephens JF (1831) Illustrations of British entomology or, a synopsis of indigenous insects: containing their generic and specific distinctions; with an account of their metamorphoses, times of appearance, localities, food, and economy, as far as practicable. Mandibulata. Volume IV. Baldwin and Cradock, London, 413 pp.

Szawaryn K, Leschen RAB (2019) Redescription and notes on the New Zealand ladybird species Hoangus venustus (Pascoe, 1875) (Coleoptera: Coccinellidae). Journal of Asia-Pacific Entomology 22(1): 226-232. https://doi.org/10.1016/j.aspen.2018.12.010

Szawaryn K, Tomaszewska W (2020) New and known extinct species of Rhyzobius Stephens, 1829 shed light on the phylogeny and biogeography of the genus and the tribe Coccidulini (Coleoptera: Coccinellidae). Journal of Systematic Palaeontology 18(17): 1445-1461. https://doi.org/10.1080/14772019.2020.1769751

Tomaszewska W, Ślipiński A (2011) Revision of the genus Rodatus Mulsant, 1850 (Coleoptera: Coccinellidae: Coccidulini). Annales Zoologici 61: 657-684. https://doi. org/10.3161/000345411X622516

Tomaszewska W (2010) Rhyzobius (Coleoptera: Coccinellidae) a revision of the world species. Fauna Mundi, volume 2, MIZ PAS, Warszawa, 475 pp.

Weinert LA, Tinsley MC, Temperley M, Jiggins FM (2007) Are we understudying the diversity and incidence of insect bacterial symbionts? A case study in ladybird beetles. Biology Letters 3: 678-681. https://doi.org/10.1098/rsbl.2007.0373

Weise J (1879) Bestimmungs-Tabellen der europaischen Coleopteren II. Coccinellidae. Zeitschrift für Entomologie, Breslau, Neue Folge 7: 88-156.

Weise J (1895) Neue Coccinelliden, sowie Bemerkungen zu bekannten Arten. Annales de la Société Entomologique du Belgique 1895: 120-146. 